\section{Sweden debates gene-splicing}

For the first time, recombinant DNA research is being publicly debated in Sweden. Some voices are calling for broad understanding and judgement of the ethical, economic and political issues involved, while others are more concerned with the security aspects of a proposed P3 laboratory at Uppsala. At the same time, the Ministry of Education is setting up a one-man commitee to see if existing Swedish laws are sufficient for the regulation of such research, or whether new legislation may be needed.

It sounds as though the country has suddenly woken up to find recombinant DNA research sitting on its doorstep. Not so. The previous government was approached about the issues as long ago as 1973, but did not respond. In 1975 Uppsala biologists applied for a P3 laboratory. In the spring of 1976 an eleven-man "Committee Concerning Research with Recombinant DNA" was set up under the auspices of the Natural Science Research Council, the Medical Research Council and the Swedish Cancer Society to ensure that such research was carried out in safety for both laboratory personnel and the public at large. The committee has decided that Sweden's risk classification system should be a combination of the British Williams' guidelines and the United States' NIH guidelines, adopting the stricter elements of each. Although the committee's mandate only covers state-supported research on recombinant DNA-and it must

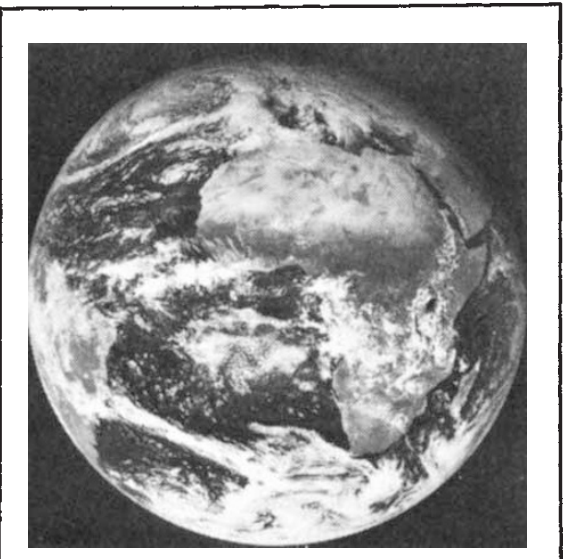

Meteosat, the European Space Agency's meteorological satellite, eventually reached geostationary orbit above the Gulf of Guinea on 7 December, after a series of false starts on the Cape Canaveral launchpad. The picture above is the first taken by the satellite at visible wavelengths, showing cloud cover above Africa and the Atlantic on 9 December 1977. approve all proposals for such research before they can begin-private industry has voluntarily agreed to follow the same procedure with its proposals.

According to the committee's chairman, Professor Peter Reichard of the Karolinska Institute, recombination of DNA within the same species (which requires only $\mathbf{P 1}$ facilities) is being done at the Karolinska Institute and the University of Uppsala, but so far no-one is doing any research needing P3 facilities. That part of the Uppsala group's work which has needed such a laboratory has been done so far at the Pasteur Institute in Paris. Private industry has not yet submitted any proposals to the committee.

Professor Lennart Philipson, who leads the Uppsala group, says he is tired of the controversy aroused by his proposed P3 laboratory. He complains that society's confidence in scientists is waning, and hopes that it will increase with public awareness of what the research involves. His new research programme, in which he will try to develop Bacillus Subtilis as an alternative host for recombinant DNA, will not need P3 facilities before 1979 . The plans for converting part of an existing building into the new laboratory should be finished before Christmas. Critics of the scheme are demanding that they should be approved not only by the DNA committee, as was the original intention, but also by the local health authorities.

Wendy Barnaby

\section{Geography affects oil spill damage}

THERE have been two significant oil spills in Scandinavian waters this year: April's Ekofisk blow-out, and leakage from the Russian tanker "Tsesis" which grounded on an unmarked rock in the Stockholm archipelago in October. Although the Bravo blow-out dumped at least six times as much oil into the water as the "Tsesis" did, preliminary research suggests that marine life in the North Sea has not suffered as much as that in the archipelago. According to a Swedish expert, the reason for this is the different geographical factors involved in the two spills.

Preliminary findings published by the Institute of Marine Research at Bergen, Norway, describe the acute effects of the Bravo blow-out on fish arid plankton as "small". An estimated 2,000 to 3,000 tons of oil at a temperature of more than $75^{\circ} \mathrm{C}$ spurted daily out of an open production pipe $20 \mathrm{~m}$ above the sea surface, shot another $30 \mathrm{~m}$ into the air (where some of it was dispersed and evaporated) and then rained down onto the sea. The pipe was capped after seven-and-a-half days. It was assumed that $40 \%$ of the cil had evaporated by then, leaving some 9,000 to 13,000 tons on the water. As its viscosity was low, it spread quickly; only 800 to 1,000 tons were recoverable by mechanical means. Chemical dispersants were assumed to increase the damage the oil would do to marine life, so they were applied very sparingly.

A week after the spill, the oil became granulated and later formed tar balls which, in June and July, were drifting over an area of $55,000 \mathrm{~km}^{2}$ in concentrations averaging $2.5 \mathrm{mg} \mathrm{m}^{-2}$ sea surface: a level considered to be heavy pollution. Close to the Bravo platform, oil-in-water emulsion under relatively freshly spilled oil was found to be in concentrations of up to about $300 \mathrm{mg} /$ litre water: but further away, it was below levels which have caused acute sublethal effects on the more sensitive stages of fish development in laboratory tests.

At the time of the spill, biological development was in its early spring stage. In a few square nautical miles around and east of the platform, the degree of photosynthesis of the phytoplankton was significantly reduced: but otherwise its development seemed normal. There were few fish, fish eggs and yolk sacs in the area at the time of the spill and for a short time afterwards, and the number and distribution of fish seemed to be unaffected by the oil.

The institute sees several factors accounting for the lack of acute effects. The escaping oil was hot, and this, combined with the action of the wind and the fact that the oil spread quickly over the surface, meant that most of the volatile and toxic compounds were evaporated. What hydrocarbons remained in the sea were diluted by unstable water conditions. Excepting the area close to the platform, the resulting hydrocarbon concentrations in the water column were low.

When the "Tsesis" ran aground in the Stockholm archipelago on 26 October, between 1,500 and 2,000 tons of the 19,000 tons of medium-grade fuel oil she was carrying spilled out into the water. The coast guard managed to contain some of the oil with booms, but winds and currents carried a large part of it to an island and part of the mainland nearby. As the wind blew steadily in the same direction for a couple of weeks after the accident, the oil stayed banked up against the shores, emulsifying down to a depth of 2 to 5 metres.

According to preliminary results from tests carried out jointly by the University of Stockholm's Askoe 
Laboratory and the Swedish Water and Air Pollution Research Laboratory, the effects so far have been relatively mild in the free water (the pelagic zone) but severe along the coast (the littoral zone). Because the accident happened in autumn, the water was cold and life processes were few and slow. This reduced the effects on both marine and bird life: less than 100 birds so far seem to have been killed. Preliminary estimates show that, within four days of the grounding, the mortality of the zoo-plankton within $400 \mathrm{~m}$ of the tanker had significantly increased, and about $35 \%$ of the zooplankton had either been touched by or ingested oil. What was dramatic, however, was the effect on the littoral zone's bladder wrack community. It was found to be almost completely deserted after the spill. Small crustaceans and molluscs either died or left the area. Laboratory studies have also indicated sublethal effects on mussels and snails.

Dr Olle Linden, who is leading the Swedish investigations, points out that the dilution factor is very important in determining the amount of damage done to marine life by oil spills. Severe ecological disasters are more likely to occur in shallow, enclosed coastal water than in the open sea, where the oil generally disperses quickly. The oil spilled from the 'Tsesis' was pinned by winds against the shore. In the end, it was the geography that made the difference.

Wendy Barnaby

\section{Correction}

The Food and Agriculture Organisation's (FAO) budget for the biennium 1978-79 will be $\$ 211,350,000$ not $\$ 237,377,000$ as indicated on page 553 of last week's issue.

\section{More natural gas for Pakistan}

PAKISTAN is the only country in the East that seems likely to cushion the energy crisis by exploiting its natural gas reserves. This has become possible because of two major discoveries of gas reserves within a matter of 12 months. According to Dr Shahzad Sadiq, Chairman of the Oil \& Gas Development Corporation (OGDC), Pakistan is now in a position to export gas in liquid form or, as a gas, through overland pipelines. The western part of India is extremely gas-hungry and the possibility of piping gas to those regions is now being actively considered.

When last December a big natural gas reserve was discovered at Dhodak, in north Pakistan, the condensate oil in the reserve stole the limelight. The then Prime Minister, Mr Zulfiqar Ali Bhutto, chose to dramatise it by bringing a bottle full of oil to the floor of the National Assembly (The Parliament), and waving it within inches of the face of the Leader of the Opposition. Pakistan, which watched the display on TV, was thrilled. Oil had been struck!

However, the Dhodak find is essentially a natural gas reserve with some 5 million million $\mathrm{ft}^{3}$ of gas. And with yet another big gas discovery only last month and again in the north (at Pirkoh in Baluchistan) the focus is now on natural gas exploitation. The Pirkoh gas reserves are estimated to match those of Dhodak.

The Chief Martial Law Administrator General Mohammad Zia-ulhaq, who at present heads the government, visited Pirkoh earlier this month to inaugurate the gas-field and formally underline the importance of the new find in the overall economy of the country. Pakistan suffers balanceof-payments difficulties which are largely due to heavy imports of oil. At Pirkoh, the OGDC Chairman told General Zia-ul-haq that an investment of $\$ 250$ million in the development of newly discovered oil and gas fields could give a return of $\$ 230$ million annually. This can be earned in oil import substitution and in export of gas and surplus petroleum products.

The gas fields at Pirkoh and Dhodak are not the largest in Pakistan. The biggest one is isolated at Sui in Baluchistan and has an estimated reserve of 10 million million $\mathrm{ft}^{3}$. It has been exploited for the last two decades. Pirkoh and Dhodak are graded next to Sui in reserve contents. The fourth largest gas field, at Mari in upper Sind, has also been exploited for some time; its estimated reserves are some 4 million million $\mathrm{ft}^{3}$. Total gas reserves in Pakistan are now estimated to reach 30 million million $\mathrm{ft}^{3}$.

The most significant impact of natural gas in Pakistan has been on agriculture. The four big fertiliser factories already in production (largely producing urea, also some ammonium nitrate and ammonium sulphate) entirely depend on the natural gas for the power and feedstock requirements. In addition, four more big fertiliser projects, based on natural gas, are under way. The green revolution that has almost doubled the average yield of wheat, the staple grain, and rice through the introduction of dwarf varieties within the last decade calls for plenty of fertilisers as its most vital input.

As a result of the two natural gas discoveries it should be feasible to set up more fertiliser and cement plants, apart from proposed exports to ease the balance of payment position.

Azim Kidwai

\section{UK Agricultural research is blooming}

In contrast to the gloomy future foreseen for British science by many of its funding agencies, the UK Agricultural Research Council's (ARC) latest annual report for 1976-77, published last week, is almost cheerful. It reports a small growth for the Council's share of the DES Science Budget for 1976-77 and a period of stability in the Council's dealings with the Ministry of Agriculture, Fisheries and Food (MAFF) and the Department of Agriculture and Fisheries for Scotland, the Council's main customers under the Rothschild customer/contractor principle.

The ARC's increased share of the Science Vote over the past two years (its grant for $1977-78$ was $1.8 \%$ up in real terms on that for 1976-77), is attributed to a growing appreciation of the need for fundamental research in agricultural and related sciences by the Advisory Board for the Research Councils (ABRC). In particular, the ARC feels that it received sympathetic consideration when the ABRC allocated the extra money set aside for the research councils after the mini budget at the beginning of last month. Of the $£ 4$ million to be added to next year's Science Vote, the ARC will get $£ 300,000$. And of the $£ 4$ million to be spent on new capital work next year it will get $£ 800,000$.

Sir William Henderson, ARC Chairman, attributes part of the Council's success in winning the
ABRC's sympathies to the work of the Priorities Working Party set up in June 1976 to select areas of basic agricultural research which could be most suitably funded from the DES Science Budget. Under the heading 'plants and soils' it chose crop variability, soil/root relationships and crop bioenergetics as priority topics for research. It has yet to select priorities in 'animals' and 'food' subjects. In line with the choice of priority topics, however, the $£ 300,000$ bonus is to be spent on setting up a programme of genetic manipulation in plants in several institutes.

The $£ 800,000$ which has been set aside for construction will most probably be spent on the improvement and the extension of existing institutes.

Judy Redfearn 